\title{
Surgical Approach to Medullary Thyroid Cancer
}

\section{revisão}

\section{CAtharina IHRE LUNDGReN LEIGH DELBRIDGE DIANA LEAROYD BRUCE ROBINSON}

University of Sydney Endocrine Surgical Unit (CIL \& LD), and Cancer Genetics Unit, Kolling Institute of Medical Research (DL \& BR), University of Sydney, Sydney, Australia.

Recebido em 31/01/07 Aceito em 02/02/07

\section{ABSTRACT}

Medullary thyroid cancer (MTC) compromises 3-5\% of all thyroid cancers and arises from parafollicular or calcitonin-producing C cells. It may be sporadic ( $75 \%$ of cases), or may occur as a manifestation of either the hereditary syndrome Multiple Endocrine Neoplasia type 2 (MEN 2A or MEN 2B) (25\% of cases), or rarely as an isolated familial syndrome (FMTC). Complete surgical resection comprising in most cases total thyroidectomy with central lymph node dissection at an early stage of the disease is the only potential cure for MTC. The familial form of the disease, MEN-2A occupies a unique place in surgical history, having been the first disease where surgical removal of an affected organ was undertaken before the development of malignancy, solely on the basis of genetic testing. Total thyroidectomy prior to the development of invasive cancer completely avoids an otherwise lethal malignancy. Timing of prophylactic surgery is based on models that utilise genotype-phenotype correlations, which have now been stratified into three risk groups based on the specific codon involved. MTC should be followed with postoperative serial serum calcitonin levels to survey for persistent or recurrent disease as indicated by detectable levels. The challenge however, if calcitonin levels are increased, is to find the source of its production. The first localisation technique recommended would be ultrasound of the neck, since there is a high frequency of local recurrence and cervical node metastasis, followed by a total body CT scan and bone scintigraphy. (Arq Bras Endocrinol Metab 2007;51/5:818-824)

Keywords: Medullary thyroid cancer; Surgery; RET gene; Multiple endocrine neoplasia type 2

\section{RESUMO}

\section{Abordagem Cirúrgica do Carcinoma Medular de Tiróide.}

O carcinoma medular de tiróide (CMT) abrange 3-5\% do câncer de tiróide em geral e surge da célula parafolicular ou célula $C$ produtora de calcitonina. Pode ser esporádico ( $75 \%$ dos casos), ou pode ocorrer como uma das manifestações das síndromes hereditárias Neoplasia Endócrina Múltipla tipo 2 (NEM2A ou NEM2B) (25\% dos casos), ou mais raramente como uma síndrome familiar isolada (CMTF). A ressecção cirúrgica completa, que na maioria dos casos consiste de tireoidectomia total com dissecção dos linfonodos nos estágios precoces da doença, é a única forma de cura potencial de CMT. A forma de doença familiar da patologia NEM2A ocupa um lugar único na história da cirurgia, tendo sido a primeira doença onde a remoção cirúrgica de um órgão afetado foi realizada antes do desenvolvimento da malignidade, baseado somente no teste genético. A tireoidectomia total antes do desenvolvimento do câncer invasivo evita de outra forma a malignidade letal. A época da cirurgia profilática está baseada nos modelos que utilizam a correlação genótipo-fenótipo, que atualmente está estratificada em três grupos de risco baseado no códon envolvido. O CMT deve ser acompanhado após a cirurgia com dosagem de calcitonina sérica, cujo nível, quando detectável, indicaria a persistência ou recorrência da doença. O desafio, no entanto, se os níveis de calcitonina estão elevados, é encontrar a fonte desta produção. A primeira técnica de localização recomendada seria o ultrassom do pescoço, já que ocorre uma alta freqüência de recorrência local e de metástase dos nódulos cervicais, seguida de tomografia computadorizada do corpo inteiro e de cintilografia óssea. (Arq Bras Endocrinol Metab 2007;51/5:818-824)

Descritores: Câncer medular de tiróide; Cirurgia; Gene RET; Neoplasia endócrina múltipla tipo 2 


\section{BACKGROUND}

M EDULLARY THYROID CANCER (MTC) compromises $3-5 \%$ of all thyroid cancers and arises from parafollicular or calcitonin-producing $\mathrm{C}$ cells. In contrast to papillary and follicular thyroid carcinomas, no difference in distribution between females and males is observed. Histologically, MTC is characterized by uniform polygonal cells with finely granular eosinophilic cytoplasm and central nuclei. C cell hyperplasia is associated with MTC, being the precursor lesion in malignant transformation to MTC. MTC may be sporadic (75\% of cases), or may occur as a manifestation of either the hereditary syndrome Multiple Endocrine Neoplasia type 2 (MEN 2A or MEN 2B) (25\% of cases), or rarely as an isolated familial syndrome (FMTC). In familial forms, tumours are usually bilateral and multifocal.

MTC is usually a slow growing tumour with an indolent clinical course, with the overall 10-year survival being reported to be around 50\% $(1,2)$. However, age at diagnosis and tumour node metastasis (TNM) stage are independent predictors of survival. For patients (other than patients with MEN 2B), under 45 years of age at the time of diagnosis with MTC confined to the thyroid, the 10 year-survival is close to $100 \%$ (3). Both the cure and survival of these patients are affected by early diagnosis (4).

Complete surgical resection comprising in most cases total thyroidectomy with central lymph node dissection at an early stage of the disease is the only potential cure for MTC (5). However, more than 50\% of the patients with MTC will have persistent disease, despite the initial total thyroidectomy, manifested as elevated postoperative calcitonin levels (6). MTC has proven to be poorly responsive to radiotherapy and chemotherapy (7). Various radical therapies including somatostatin analogues and imodium may be effective in controlling diarrhoea and flushing.

The surgical management of patients with MTC continues to evolve, largely based on the way in which it is diagnosed. Since the mid-1990s, genetic testing for mutations in the RET proto-oncogene has allowed earlier diagnosis of at-risk family members for the familial forms of MTC. RET mutation carriers are now offered prophylactic surgery before the development of MTC, the age of surgery being determined by risk.

\section{CLINICAL PRESENTATION}

The most common clinical presentation of sporadic medullary thyroid carcinoma is a solitary thyroid nodule.
Other simultaneous symptoms such as diarrhoea and or a flushing syndrome are usually related to advanced metastatic disease. The hereditary form might be suspected on the basis of a positive family history or the association with other endocrine neoplasia (such as pheochromocytoma and/or parathyroid adenoma) or other related syndromes to MEN 2 (such as Marfanoid features, von Hippel Lindau disease and neuromas). The evaluation of the thyroid nodule is performed the same way in hereditary forms as in sporadic forms, but further investigations to exclude coexisting adrenal and parathyroid disease are mandatory in the hereditary forms.

\section{Diagnosis}

A palpable nodule or a multinodular goitre is usually present and a classical workup for thyroid disease is then performed. In most cases, fine needle biopsy will provide a definitive diagnosis before surgery, however MTC may also be diagnosed after surgery in patients with multinodular goitre and multiple nodules, not all of which will have been biopsied. Cytological suspicion of MTC should be followed by measurement of serum calcitonin levels. Some groups $(8,9)$ recommend routine calcitonin screening for all patients with presenting with thyroid nodules and multinodular goitre, providing another means of clinical presentation.

\section{Genetic testing}

It is recommended that routine RET mutation analysis should be performed on all "apparently sporadic" cases of MTC where the prevalence of familial disease is reported to be between $6 \%$ and $25 \%(10,11)$. Screening for RET gene mutations allows the early discovery of gene carriers, who can then be treated with prophylactic thyroidectomy, providing the only chance of definitive cure of this potentially lethal thyroid disease $(12,13)$. Over 20 RET codon mutations have now been described and specific genotype-phenotype correlations are allowing for more tailored approaches to surgical treatment and timing of surgery for patients with MTC (14).

Likewise all at-risk members of known MEN 2 or FMTC kindred should have genetic testing. Hereditary MTC has an autosomal dominant pattern of inheritance and is caused by activating germline point mutations in the RET proto-oncogene (15). The penetrance of RET mutations is close to $100 \%$, which means that all gene heterozygous carriers will eventually develop MTC (16).

Genetic testing also allows for the exclusion of pheochromocytoma and hyperparathyroidism, both of which are found in MEN 2. It is important the diag- 
nosis is excluded in all cases of MTC prior to surgery with either a negative genetic screening or by measuring catecholamines as well as serum calcium and PTH.

\section{SURGICAL APPROACH}

The surgical treatment for MTC is influenced by several factors. First the clinical course of MTC is usually more aggressive than that of non-medullary differentiated thyroid cancer, with high rates of recurrence and mortality, especially in young patients. Secondly, nodal metastases are present in more than $70 \%$ of patients with palpable disease (17). Thirdly, MTC cells do not take up radioactive iodine, and radiotherapy and chemotherapy are ineffective and, fourthly, the ability to measure postoperative calcitonin levels allows assessment of the adequacy of surgical extirpation. Additionally, MTC is multicentric in $90 \%$ of patients with hereditary forms and in $20 \%$ of patients with the sporadic form of the disease. In all patients with a diagnosed MTC, total thyroidectomy and central lymph node dissection is the minimum appropriate treatment. More extensive neck dissection is indicated for larger tumours, multicentric disease, or where central node involvement is demonstrated.

\section{Total thyroidectomy}

Total thyroidectomy involves removal of all visible thyroid tissue bilaterally. "Near-total thyroidectomy", an operation promoted in some centres as an alternative to "total thyroidectomy" is absolutely inappropriate for patients with MTC. The aim of near-total thyroidectomy is to preserve a small postero-lateral remnant of thyroid tissue in the region of the Tubercle of Zuckerkandl (18), in order to protect the vascular supply of the parathyroid glands as well as the recurrent laryngeal nerve. It is the Tubercle of Zuckerkandl, however, that derives embryologically from the fourth branchial cleft, along with the C-cells and the ultimobranchial body. Thus that very area of thyroid tissue is the one with the highest concentration of C-cells and the highest likelihood of having an MTC present. Total thyroidectomy for MTC must aim at meticulous excision of all the posterolateral thyroid tissue including the Tubercle of Zuckerkandl (19).

\section{Central neck dissection}

Individual practice in relation to what constitutes a "central lymph node dissection" varies considerably in centres worldwide. The American Joint Committee on Cancer (AJCC) classifies lymph nodes in the neck into seven levels. They are: level I, submental and submandibular; level II, upper internal jugular nodes, from skull base to hyoid bone; level III, middle internal jugular nodes from hyoid bone to the lower margin of the cricoid cartilage; level IV, inferior internal jugular nodes from omohyoid muscle to clavicle; level V, spinal accessory and transverse cervical nerve and supraclavicular lymph nodes; level VI, paralaryngeal, paratracheal and prelaryngeal nodes adjacent to the thyroid gland from the hyoid to the sternum; and level VII, the retromanubrial upper anterior mediastinum node including the thymus gland (20). Dissemination of thyroid cancer cells through the lymphatic system of the neck is believed to evolve in a stepwise manner. Nodal metastases begin in the central (level VI) for tumours in the body and lower pole, and in the immediately adjacent jugular nodes for upper lobe lesions, then progressively spread to other jugular nodes, and then to the lateral, contralateral jugular and mediastinal nodes. Thus many define a "central neck dissection" as comprising simply a bilateral level VI dissection, whereas others include the retromanubrial nodes (level VII). Dralle includes in the "central compartment" (Dralle levels la and $\mathrm{lb}$ ) all lymph nodes medial to the internal jugular veins bilaterally, from the hyoid to the manubrium, and believes that this is superior to the AJCC definition as it encompasses an anatomic compartment with defined borders amenable to consistent surgical dissection (21). Still others dissect more widely including a formal dissection of levels III and IV (lower jugular nodes) bilaterally. The practice in our unit is to take an anatomical approach to lymph node tissue contiguous to the thyroid, thus we define a "central node dissection" as including all tissue medial to the jugular veins bilaterally from the hyoid down to and including the retromanubrial tissue to the innominate vein.

\section{Selective neck dissection}

For patients with more extensive primary disease, e.g. large or multicentric tumours, or where central node involvement is evident, more extensive neck dissection is warranted. Selective neck dissection is based on the concept that lymph nodes in the neck do not form a continuous sheet but are grouped as per the above AJCC definitions. Surgical excision is thus best directed at the removal of those specific nodes most likely to be involved. In the first instance, removal of the next level of potentially involved nodes, e.g. ipsilateral level II and ipsilateral level V (= lateral neck nodes) is indicated. Occasional patients will require bilateral central plus bilateral lateral plus mediastinal node dissection 
(Dralle 4 compartment procedure) in order to achieve effective disease clearance (21).

A systematic approach to the removal of all nodal tissue in the central neck has been reported to improve recurrence and survival rates when compared retrospectively with procedures in which only grossly involved nodes were removed (22). Moley et al. showed that in patients with a palpable MTC, lymph node metastases were present in $80 \%$ of the central nodes, in $75 \%$ of the ipsilateral jugular nodes (levels II-IV) and in $47 \%$ of contralateral jugular nodes. In this series, the intraoperative palpation of nodes was not an accurate predictor of the presence or absence of metastases $(17,23)$. From data on lymphatic dissemination of MTC $(21,24)$, it seems as if the ipsilateral cervical lymph node compartments constitute the border between local and systemic disease. Contralateral lymphatic drainage of tumour cells is indicative of systemic disease, as evidenced by the frequent failure of calcitonin level to normalize despite extensive lymph node dissection. Machens et al. showed that calcitonin levels rarely normalize when 10 or more lymph nodes are positive $(24,25)$.

In symptomatic patients, MTC is frequently node-positive and more advanced. They found that the ipsilateral cervical lymph node compartments were like a watershed between local and systemic disease. Patients whom already had progressed beyond the ipsilateral nodal groups were usually not curable by the addition of surgical lymphadenectomy of distant lymph node compartments. Thus, contralateral lymphatic drainage of tumour cells is indicative of systemic disease, as evidenced by the frequent failure of calcitonin levels to normalise despite extensive lymph node dissection (25). Clearance of lymph node metastases by systematic dissection may achieve local control in the neck and mediastinum, preventing tumour penetration into esophageus and trachea. From a surgical point of view it is important to distinguish between local disease, which may be curable, and systemic disease, where the goal of treatment is palliative.

\section{Concurrent disease in MEN 2A patients}

These patients will frequently have co-existing phaeochromocytoma and hyperparathyroidism requiring surgical excision. Phaeochromocytoma must be excluded initially and should be treated surgically, after appropriate blockade, on a separate occasion prior to thyroid surgery due to the potentially lethal consequences of anaesthesia in such patients. Parathyroid disease should be search for and dealt with surgically, if present, at the time of total thyroidectomy. Patients with MEN2A have one or more enlarged parathyroid glands, rather than true four-gland hyperplasia. Thus parathyroid surgery is directed at removal of the enlarged parathyroid glands only (26). Subtotal parathyroidectomy is not necessary and, indeed, will be associated with an unacceptably high incidence of post-operative hypoparathyroidism

\section{POSTOPERATIVE SURVEILLANCE}

Serum calcitonin is a well-established sensitive and specific marker for MTC. Therefore all patients undergoing thyroidectomy for MTC should be followed with postoperative serial serum calcitonin levels to survey for persistent or recurrent disease as indicated by detectable levels. In patients with a palpable tumour at the time of diagnosis, $50 \%$ will have an elevated level of calcitonin postoperatively. In patients with lymph node involvement it may be as high as 70\% (27). Fersht et al. studied 139 patients with MTC, 51 had persistent elevated calcitonin levels after surgery, in the absence of clinically or radiologically demonstrable residual disease. Of these, 24 were treated with radiotherapy and 27 had no treatment. Local relapse rate was significantly lower after radiotherapy but there was no significant difference in 10-year survival between theses two groups (28). In patients with persistent disease a serum CEA concentration should also be monitored.

However, the challenge if calcitonin and CEA levels are increased is to find the source of its production. The first localisation technique recommended would be ultrasound of the neck, since there is a high frequency of local recurrence and cervical node metastasis, followed by a total body CT scan and bone scintigraphy. Other imaging techniques such as Octreoscan, 123I-MIBG and PET (positron emission tomography) may be useful, but they are not particularly sensitive. Selective venous sampling is an accurate technique to localise occult metastases. The presence of a gradient in the neck, after venous selective sampling catherization, in the mediastinum or in the suprahepatic veins suggests the presence of metastatic disease in the area where the higher levels of serum calcitonin have been found (16). In the absence of visible disease by imaging, there are two options: observation with interval surveillance CT scans of the chest, abdomen and neck or reoperation in the neck if a nodal clearance was not already performed.

Metastatic MTC to the liver often has a miliary appearance with small, white, raised nodules on the liver surface, often multiple, they can easily be visu- 
alised with the laparoscope, but not by CT, MRI or other imaging scans. Quayle et al. showed that in a series of 41 patients, liver metastases were demonstrated in 8 patients, 7 of whom had a negative CT imaging (23). In an update of this series they also showed that liver metastases were identified in $21 \%$ of the patients by laparoscopy, whereas imaging (CT, MRI and nuclear scans) had a sensitivity of $7 \%$ and a false negative rate of $20 \%$ (29).

\section{FAMILIAL DISEASE}

$25 \%$ of all MTC are hereditary, mainly MEN 2A, MEN $2 \mathrm{~B}$ and familial medullary thyroid cancer (FMTC). Pattern of inheritance are autosomal dominant and all known MEN 2 variants are caused by mutations in the RET proto-oncogene. MEN 2A is caused by mutations at extracellular cysteine residues, MEN 2B is caused by a methionine to threonine mutation at codon 918 in the tyrosine kinase catalytic domain, and FMTC is caused by the same mutations as MEN 2A, as well as by less common mutations in the extracellular portion of the protein (23).

MEN-2A occupies a unique place in surgical history, having been the first disease where surgical removal of an affected organ was undertaken before the development of malignancy, solely on the basis of genetic testing. It has been the paradigm for developing such approaches in that, unlike all other familial cancers, e.g. familial breast cancer, all the criteria are present in that there exists an accurate diagnostic genetic test, there is minimal morbidity from the surgical intervention of total thyroidectomy, organ function is able to be fully replaced with thyroxine and a test of subsequent disease status (calcitonin) is available. The extent and timing of thyroidectomy, as well as the management of lymph nodes and parathyroid glands, depends on the specific RET codon harbouring the mutation. Timing of surgery is based on models that utilise genotype-phenotype correlations, which have now been stratified into three risk groups based on the specific codon involved $(30,31)$. Level 3 mutations (codons 883 and 918) are the highest risk of early development and growth of MTC, prophylactic thyroidectomy should be performed by the age of 6 months. Current guidelines for the treatments of patients with level 2 (codons 611, 618, 620 and 634) mutations recommend total thyroidectomy by the age of 5 years. The aggressiveness and penetrance of MTC in level 1 (codons 609, 768, 790, 791, 804 and 891) mutations seem to be lower and patients may develop
MTC at a higher age. The optimal timing for surgery is still controversial and decision for thyroidectomy in level 1 mutation carriers has to be individualised. However, we recommend that surgery is undertaken as close as possible to the earliest reported age of onset for each specific genotype (13).

Once prophylactic surgery is agreed, there are two options, namely total thyroidectomy alone, or total thyroidectomy, central node dissection with or without parathyroidectomy with autotransplantation (23). The advantage of total thyroidectomy alone is that it is a standard familiar operation. There is, however, a higher potential risk of local recurrence if MYC is present, because it leaves central lymph nodes that may be the site of recurrence. A more complete removal of thyroid and nodal tissue is performed if total thyroidectomy, central lymph node dissection are performed. However, the disadvantages of this operation is an increased risk of complications that takes more time, it should only be performed by surgeons experienced in thyroid and parathyroid operations.

Clinical expression of the MEN 2 variants is widely variable, its aggressiveness and clinical course varies between clinical subtypes. This has led to different recommendations regarding the timing of thyroidectomy for children with different classes of mutation. MTC in the setting of MEN 2B is generally most aggressive, with invasive carcinoma often present in the first year of life and lymph node metastases reported by the age of 2 .

Prophylactic total thyroidectomies should be carried out regardless of serum calcitonin level. Increased calcitonin levels correlate to the presence of already established MTC, clearly necessitating total thyroidectomy whereas the goal for prophylactic surgery is resection of the thyroid gland before the presence of tumour cells and their precursor lesions. Calcitonin levels help predict MTC tumour load, however the levels themselves do not change the need for total thyroidectomy in patients with RET codon mutations. From our own data, of one of the largest MEN 2A-families, we suggested that there appears to be age-related progressions of MTC in patients with RET codon 804 mutation (26). Others have also observed this age-related progression of disease. A recent multicentre study from Europe described 207 patients with RET codon mutations who underwent prophylactic thyroidectomy with lymph node dissection, where the mean age at diagnosis was 6.9 years for patients with C-cells hyperplasia, 10.1 years for nodenegative MTC and 16.7 years for node-positive MTCpatients (32). 
In patients with familial disease, controversy exists over the optimal management of the parathyroid glands. Some argue for four-gland parathyroidectomy with autotransplantation, on the basis that an adequate central neck dissection is not possible if the parathyroid glands are left in place with sufficient blood supply (33). Others argue that only grossly enlarged parathyroid glands should be removed, since an aggressive management of normal parathyroid glands is associated with a higher incidence of hypoparathyroidism, and a need for some patients to be on calcium and vitamin D supplementation for the rest of their lives.

\section{REFERENCES}

1. Bergholm U, Bergstrom R, Ekbom A. Long-term follow-up of patients with medullary carcinoma of the thyroid. Cancer 1997;79(1):132-8.

2. Gulben K, Berberoglu U, Boyabatli M. Prognostic factors for sporadic medullary thyroid carcinoma. World J Surg 2006;30(1):84-90.

3. Kebebew E, Ituarte $\mathrm{PH}$, Siperstein $\mathrm{AE}$, Duh $\mathrm{QY}, \mathrm{Clark} \mathrm{OH}$. Medullary thyroid carcinoma: clinical characteristics, treatment, prognostic factors, and a comparison of staging systems. Cancer 2000;88(5):1139-48.

4. Elisei R, Bottici V, Luchetti F, Di Coscio G, Romei C, Grasso L, et al. Impact of routine measurement of serum calcitonin on the diagnosis and outcome of medullary thyroid cancer: experience in 10,864 patients with nodular thyroid disorders. J Clin Endocrinol Metab 2004;89(1):163-8.

5. Chen H, Roberts JR, Ball DW, Eisele DW, Baylin SB, Udelsman $R$, et al. Effective long-term palliation of symptomatic, incurable metastatic medullary thyroid cancer by operative resection. Ann Surg 1998;227(6):887-95.

6. Hahm JR, Lee MS, Min YK, Lee MK, Kim KW, Nam SJ, et al., Routine measurement of serum calcitonin is useful for early detection of medullary thyroid carcinoma in patients with nodular thyroid diseases. Thyroid 2001;11(1):73-80.

7. Nocera M, Baudin E, Pellegriti G, Cailleux AF, MechelanyCorone C, Schlumberger M. Treatment of advanced medullary thyroid cancer with an alternating combination of doxorubicin-streptozocin and 5 FU-dacarbazine. Groupe d'Etude des Tumeurs a Calcitonine (GETC). Br J Cancer 2000;83(6):715-8.

8. Mirallie E, lacobone M, Sebag F, Henry JF. Results of surgical treatment of sporadic medullary thyroid carcinoma following routine measurement of serum calcitonin. Eur J Surg Oncol 2004;30(7):790-5.

9. lacobone M, Niccoli-Sire P, Sebag F, De Micco C, Henry JF. Can sporadic medullary thyroid carcinoma be biochemically predicted? Prospective analysis of 66 operated patients with elevated serum calcitonin levels. World J Surg 2002;26(8):886-90

10. Wohllk N, Cote GJ, Bugalho MM, Ordonez N, Evans DB, Goepfert $\mathrm{H}$, et al. Relevance of RET proto-oncogene mutations in sporadic medullary thyroid carcinoma. J Clin Endocrinol Metab 1996;81(10):3740-5.

11. Eng C, Mulligan LM, Smith DP, Healey CS, Frilling A, Raue F, et al. Low frequency of germline mutations in the RET protooncogene in patients with apparently sporadic medullary thyroid carcinoma. Clin Endocrinol (Oxf) 1995;43(1):123-7.
12. Pacini F, Romei C, Miccoli P, Elisei R, Molinaro E, Mancusi F, et al. Early treatment of hereditary medullary thyroid carcinoma after attribution of multiple endocrine neoplasia type 2 gene carrier status by screening for ret gene mutations. Surgery 1995;118(6):1031-5.

13. Cote GJ, Gagel RF. Lessons learned from the management of a rare genetic cancer. N Engl J Med 2003;349(16):1566-8.

14. Machens A, Ukkat J, Brauckhoff M, Gimm O, Dralle H. Advances in the management of hereditary medullary thyroid cancer. J Intern Med 2005;257(1):50-9.

15. Ogilvie JB, Kebebew E. Indication and timing of thyroid surgery for patients with hereditary medullary thyroid cancer syndromes. J Natl Compr Canc Netw 2006;4(2):139-47.

16. Pinchera AE. Medullary thyroid cancer: diagnosis and management. In: Mazzaferri EL (ed). Practical Management of Thyroid Cancer. London: Springer-Verlag, 2006. pp. 255-73.

17. Moley JF, DeBenedetti MK. Patterns of nodal metastases in palpable medullary thyroid carcinoma: recommendations for extent of node dissection. Ann Surg 1999;229(6):880-7; discussion 887-8.

18. Gauger PG, Delbridge LW, Thompson NW, Crummer P, Reeve TS. Incidence and importance of the tubercle of Zuckerkandl in thyroid surgery. Eur J Surg 2001; 167(4):249-54.

19. Delbridge L. Total thyroidectomy: the evolution of surgical technique. ANZ J Surg 2003;73(9):761-8.

20. Greene FL, Fleming ID, Fritz A, Haller DG, Morrow M, et al. AJCC cancer staging manual. $6^{\text {th }}$ ed. Berlin: Springer, 2002.

21. Machens A, Hinze R, Thomusch O, Dralle H. Pattern of nodal metastasis for primary and reoperative thyroid cancer. World J Surg 2002;26(1):22-8.

22. Dralle H, Damm I, Scheumann GF, Kotzerke J, Kupsch E, Geerlings $\mathrm{H}$, et al., Compartment-oriented microdissection of regional lymph nodes in medullary thyroid carcinoma. Surg Today 1994;24(2):112-21.

23. Quayle FJ, Moley JF. Medullary thyroid carcinoma: including MEN 2A and MEN 2B syndromes.J Surg Oncol 2005;89(3):122-9.

24. Machens A, Gimm O, Ukkat J, Hinze R, Schneyer U, Dralle H. Improved prediction of calcitonin normalization in medullary thyroid carcinoma patients by quantitative lymph node analysis. Cancer 2000;88(8):1909-15.

25. Machens A, Holzhausen HJ, Dralle H. Contralateral cervical and mediastinal lymph node metastasis in medullary thyroid cancer: systemic disease? Surgery 2006;139(1):28-32.

26. Gosnell JE, Sywak MS, Sidhu SB, Gough IR, Learoyd DL, Robinson BG, et al. New era: prophylactic surgery for patients with multiple endocrine neoplasia-2a. ANZ J Surg 2006;76(7):586-90.

27. Block MA, Jackson CE, Tashjian AH, Jr. Management of occult medullary thyroid carcinoma: evidenced only by serum calcitonin level elevations after apparently adequate neck operations. Arch Surg 1978;113(4):368-72.

28. Fersht N, Vini L, A'Hern R, Harmer $C$. The role of radiotherapy in the management of elevated calcitonin after surgery for medullary thyroid cancer. Thyroid 2001;11(12):1161-8.

29. Cohen MS, Moley JF. Surgical treatment of medullary thyroid carcinoma. J Intern Med 2003;253(6):616-26.

30. Learoyd DL, Gosnell J, Elston MS, Saurine TJ, Richardson AL, Delbridge LW, et al. Experience of prophylactic thyroidectomy in multiple endocrine neoplasia type 2A kindreds with RET codon 804 mutations. Clin Endocrinol (Oxf) 2005;63(6):636-41.

31. Frank-Raue K, Buhr H, Dralle H, Klar E, Senninger N, Weber T, et al. Long-term outcome in 46 gene carriers of hereditary medullary thyroid carcinoma after prophylactic thyroidectomy: impact of individual RET genotype. Eur $\mathbf{J}$ Endocrinol 2006;155(2):229-36. 
32. Machens A, Niccoli-Sire $P$, Hoegel J, Frank-Raue $K$, van Vroonhoven TJ, Roeher HD, et al.; European Multiple Endocrine Neoplasia (EUROMEN) Study Group. Early malignant progression of hereditary medullary thyroid cancer. $\mathbf{N}$ Engl J Med 2003:349(16):1517-25.

33. Herfarth KK, Bartsch D, Doherty GM, Wells SA, Lairmore TC. Surgical management of hyperparathyroidism in patients with multiple endocrine neoplasia type 2A. Surgery 1996;120(6):966-73; discussion 973-4.
Address for correspondence:

Bruce Robinson

University Clinic

Royal North Shore Hospital

St Leonards, NSW, 2065, Sydney, Australia

E-mail: bgr@med.usyd.edu.au 